\title{
Covid and Orthopaedics
}

\section{B. Shivashankar ${ }^{1}$, Terrence Jose Jerome}

It would be too early to say that we have surpassed COVID-19 and immature to say that we have conquered it. What would be apt is we learn from our experience and the sore failures that mellowed this pestilence. Many times, we have lost our dear and near ones.

Sometimes it flooded us with frustration, anger, and sadness over the virus and its powerful impact on our lives. But what surprises us is that the squirreling pandemic unified us to emerge more vibrant and optimistic. Also, we have seen a paradigm shift in outpatient consultations, elective operating procedures, and the beneficial use of telemedicine during such odd times.

Additionally, we focused our educational vibes on webinars and online discussion forums. Slowly we recuperated and excelled in all the stages of the pandemic and managed to live with it. The practice of medicine has taken its ordinary discourse and started its previous practicing style. The World Health Organization has efficiently wiped all the myth busters (HCQ, Ivermectin, bleach, antibiotics, vitamins, etc.) about the covid and illustratively narrated the safety norms (masks, sanitizers) [1].

Orthopedic surgeons' practices have also resurged from the dreadful pandemic and its gloomy cower. As usual, we have started elective surgeries, found better ways to deliver healthcare, and formulated innovative action measures. This gave birth to more daycare surgeries and minimally invasive procedures, which could be the modern practice too. In the meanwhile, we always performed a standard pre-screening for COVID and efficiently treated all elective surgeries. We allocated more resources, segregated COVID-positive patients from the screening, and treated them at home quarantine/ dedicated facilities. Though fear was a deterrent, we performed all emergency procedures following pre and postoperative preventive measures.

The webinars have been swapped to physical conferences and we are ready for a face-face meet. Various national and international conferences rejiggered into hybrid mode and encouraged in-person meetings, matching the standard safety norms. However, we are always cautious with time-tested quarantine, social distancing, wearing masks, and washing hands.

We need to focus on the future and have preferences in all aspects. The orthopaedics and allied specialty residents have spent most of their time in covid wards, managing the acute crises in hospitals and teaching institutions. It's high time for us to redirect them to the orthopaedic units and spend time improving their patient care skills to become efficient independent budding surgeons. Notably, we must make dramatic arrangements for the residents and train them with an innovative curriculum. It's time to roll up our sleeves, march forward metaphorically, get vaccinated, and persuade our colleagues and fellow citizens to get vaccine shots aiming for herd immunity. If not now, then when?

There has been few silver linings too due to the pandemic. The healthcare spending by government has increased by many folds and everyone is now aware of the importance of basic necessities like medicines, oxygen, ventilators, etc. Many new players who were not in healthcare industries earlier have jumped to manufacture ventilators, PPE Kits and other paraphernalia required in medical industry. Definitely over the years we shall have more indigenisation in the equipment required as well as better equipped hospitals. Over all we shall be more atmanirbhar or self-reliant as far as our health care industry is considered.

Though a return to pre-pandemic normalcy is a mire, for the destined future, our patients and we should continue wearing masks in the hospitals and follow WHO standard safety measures.

Future conferences encourage in-person meetings with mandatory vaccination. Virtual options can be kept for colleagues who are not vaccinated or unable due to various strong reasons. Widespread vaccination is the only specific or reliable method to assuage the fear and stop the raging virus.

${ }^{1}$ Consultant Orthopaedic Surgeon and Traumatologist, Iyer Orthopaedic Centre, 103, Railway Lines, SOLAPUR-413001, Maharashtra, India

Address of Correspondence

Dr. B Shivashankar,

Consultant Orthopaedic Surgeon and Traumatologist, Iyer Orthopaedic

Centre, 103, Railway Lines, SOLAPUR-413001, Maharashtra, India

E-mail: drbshivashankar@gmail.com
As we have transited many waves of the pandemic, we must provide reassurance and promote vaccination and continued social distancing for the greater good of the public. We are still positive and looking ahead with sceptical and unpredictable reality in the coming years. At the same time, we humans are inheritably bound to personal touch and socialization.

We all know that freedom comes with risk, and long-lasting adaptations to the new future are necessary. Eliminating the virus and achieving herd immunity and returning to normalcy is the expected norm, but without risk, is there hope? We are all in together and have emerged more robust than ever in combating this virus.

Declaration of patient consent: The authors certify that they have obtained all appropriate patient consent forms. In the form, the patient has given his consent for his images and other clinical information to be reported in the Journal. The patient understands that his name and initials will not be published, and due efforts will be made to conceal his identity, but anonymity cannot be guaranteed.

Conflict of Interest: NIL; Source of Support: NIL

\section{References}

1. https://www.who.int/emergencies/diseases/novel-coronavirus-2019/advicefor-public/when-and-how-to-use-masks (accessed on 6th November 2021)

Conflict of Interest: NIL

Source of Support: NIL

\section{How to Cite this Article}

Shivashankar B, Jerome TJ, Covid and Orthopaedics. Journal of Clinical Orthopaedics July-Dec $2021 ; 6(2): 1$.

Submitted Date: 15 July 2021, Review Date: 13 June 2021, Accepted Date: 16 Aug 2021 \& Published Date: 31 Dec 2021

Journal of Clinical Orthopaedics | Available on www.jcorth.com |DOI:10.13107/jcorth.2021.v06i02.440 This is an Open Access article distributed under the terms of the Creative Commons Attribution NonCommercial-Share Alike 4.0 License (http://creativecommons.org/licenses/by-nc-sa/4.0) which allows others to remix, tweak, and build upon the work non-commercially as long as appropriate credit is given and the new creation are licensed under the identical terms. 